Portland State University

PDXScholar

University Honors Theses

University Honors College

$5-25-2018$

Day of Self-Care at Trillium Family Services

Courtney M. Bladen

Portland State University

Follow this and additional works at: https://pdxscholar.library.pdx.edu/honorstheses

Let us know how access to this document benefits you.

Recommended Citation

Bladen, Courtney M., "Day of Self-Care at Trillium Family Services" (2018). University Honors Theses.

Paper 552.

https://doi.org/10.15760/honors.558

This Thesis is brought to you for free and open access. It has been accepted for inclusion in University Honors Theses by an authorized administrator of PDXScholar. Please contact us if we can make this document more accessible: pdxscholar@pdx.edu. 
Day of Self-Care at Trillium Family Services

Courtney M Bladen

An undergraduate honors thesis submitted in partial fulfillment of the

requirement for the degree of

Bachelor of Science

In

University Honors

And

Psychology

Thesis Adviser: Sandy Boyle

Portland State University

2018

Author's Note

Special thanks to Shanin Engman for the hands-on guidance in organizing and executing this event. 


\begin{abstract}
This paper is the documentation of the planning, execution, and reflection of the event Day of Self-Care at Trillium Family Services Parry Center. Self-care is a tool used by many people to make sure they are taking care of themselves mentally and physically. Before the actual event, I researched self-care and different ideas that could be done at the event. This research included journal articles, volunteering, exploring my own self-care, and collaborating with staff at Trillium. When planning the event, we relied on donations from the community for supplies that were required, making sure that we followed the quarterly timeline, and that the stations were appropriate for the in-patient clients. This event was put on so that the kids at the Parry Center could expand their view of self-care and gain tools to put in their toolbox for when they get discharged. Self-care tools at the event included journal decorating, healing scent bracelet making, vision board making, nail painting, and makeup/face painting. This event ending up being extremely successful with the kids giving the event amazing ratings, suggestions for future events, and requests that the event occur more often.
\end{abstract}




\section{Day of Self-Care at Trillium Family Services}

Self-care is a common tool to make sure that you are taking care of yourself both mentally and physically. Self-care at Trillium Family services follows the Sanctuary Model. The Sanctuary Model has the mission to "teach individuals and organizations the necessary skills for creating and sustaining nonviolent lives and nonviolent systems and to keep believing in the unexplored possibilities of peace and well-being for all of humanity" (Bloom, 2017). The Sanctuary Model has ten main pillars to accomplish its mission: visibility and empowerment, empathy, nonviolence, emotional intelligence, inquiry and social learning, equity and inclusion, democracy, open communication, social responsibility, lastly, growth and change (Bloom, 2017). These pillars work to change the stigma around mental health so that when adolescents leave Trillium they leave with tools to take care of themselves in a society where mental health is not a top value.

Trillium regularly reviews critical incident data, and since The Sanctuary Model implementation began, The Trillium Family Services Children's Farm Home Campus in Corvallis has seen significant improvements. There has been a $72 \%$ decrease in seclusion and restraints used (Vandergon, 2017, slide 6). This is an important factor when considering the Sanctuary environment because it means less trauma for the kids if they have to spend less time in restraints. But it also means less trauma for caregivers as they won't have to use restraints as often. Another statistic from the Children's Farm Home Campus is that peer to peer physical aggression decreased by $75 \%$ after the implementation of the Sanctuary Model (Vandergon, 2017, slide 9). This statistic means that the children in the residential treatment program are not hurting each other. It would be tough to try to work on your own health if you are afraid that your peers are going to harm you. 
Day of Self-Care is an ongoing project at the Parry Center Campus and is done quarterly. The event has the goal to provide the kids with ideas for self-care that they can complete outside of the facility when they go home. Previous events have had stations such as healing scent bracelet making, knitting, nail painting, art, and affirmation cards. The event discussed in the paper had the five stations: journal decorating, healing scent bracelet making, vision board making, nail painting, and makeup/face painting. This was my work to work with the existing model of self-care day and use research to improve the stations and ideas provided.

\section{Stations}

\section{Journaling}

Steve Colori (2015) wrote a first-person account of how journaling helped him with his diagnosis and experience of Schizophrenia. He discussed journaling as giving him a sense of liberation as well as functionality because he could clear his mind and write his thoughts on paper, but also work through his traumatic experiences when writing (Colori, 2015). Colori (2015) stated, "I also write social insights which gave me a better sense of how to interact, precepts for life, insights into finding better ways to think and communicate, and most importantly I use my journal to identify the things I am afraid of' (p. 2). This was an important part of his article because it illustrated the many uses that journaling can have, and the tremendous effect it can have on an individual.

Mark Stone (1998) writes about a few of his clients and their experiences with journaling. He speaks to the many different formats that journaling can take. For example, one client wrote letters while another used journaling as planning (Stone, 1998). While Stone didn't require his clients to journal, he stated that each them found journaling as a "useful tool" within their therapy (1998, p. 541). Most of all they found that journaling provided a quiet time for them to 
reflect and work through their issues in life (Stone 1998). An interesting idea that Stone makes is his emphasis on the fact that the journal is the client's property and they should not be required to share every detail or show it to the therapist (1998).

Journaling is an activity that the residents at Parry Center partake in often. To enhance their experience in journaling, one of the stations during the Day of Self-Care is going to be journal decorating. This will help the residents understand that the journal they are writing in is theirs and if they enjoy what it looks like maybe they will enjoy journaling and continue with it as self-care when they are discharged.

\section{Aromatherapy}

Aromatherapy is something that has become popular for the variety of ways that essential oils can help an individual. Brian Cook and Edzard Ernst (2000) found that an aromatherapy massage is helpful in reducing anxiety but not enough to be prescribed as a treatment for anxiety. This helps to understand it can be seen that use of essential oils will help an individual but not enough to warrant a treatment plan. This means that it is perfect for self-care. People can use it how they need it. Diego et al. stated, “Aroma molecules have direct effects on human behavior and physiology ranging from activation of memories to changes in mood or emotional states" (2001, p.217-218). This means that people will react and respond to the scents that they are smelling such as essential oils. In the study done by Diego et al. they found that Lavender and Rosemary's essential oils reduced the anxiety of the participants and that lavender had the effect increasing the participants' moods (2001). From this finding, we can see the beneficial effects that essential oils and scents have on individuals.

To connect this idea of aromatherapy to Day of Self-Care there will be a station for healing scent bracelet making. This will be a station for the kids to do something creative and 
keep their hands busy. They will be able to use several different essential oils to scent their bracelet for the effects that they would like. This is a station where they will get to keep the item that they create so that the self-care of the oil can go with them. This bracelet will also serve as a reminder to practice self-care when they need to.

\section{Vision Boards}

Visualization is a powerful tool in which an individual envisions actions or outcomes that they would like to accomplish. This has been a tool that Olympic athletes have used for decades to help them perform better in competition. Robert Weinberg (2008) defines imagery as "using all the senses (or at least all senses that are appropriate) to create or re-create an experience in the mind" (Definition of Imagery section, para. 1). In Ungerleider and Golding (1991) they described the idea of visualization as a "psyching up...that provides an over-all arousal for more optimal performance" (p. 1008). This is important to understand because athletes need to have their muscles ready to go in order to be at peak performance. Another finding from Ungerleider and Golding (1991) is the potential recommendation from medical providers for visualization when there are physical limitations. This can help athletes train when they can't physically train the way they want to. At Trillium kids could work on the ways they want to act or things they would like to accomplish in the future even if they can't actually do it yet. Weinberg (2008) found through his literature review that there is a hypothesis that self-efficacy can be enhanced by accomplished tasks and that imagery can help do this. This is important to understand fully because increased self-confidence is important for kids at Trillium. If visualization and imagery could help with this, then maybe a vision board would be helpful in their therapy. Through the literature review done by Weinberg, it was concluded that imagery had a positive effect on the performance of the athletes. (2008). 
To apply this idea to the Parry Center, I decided to have a station of vision boards that the kids had an option of making. This is something that they would be able to hang-up in their units and see every day. This important to visualization because of the repeated exposure and repeated visualization of what they want to accomplish. This would be a very attractive activity because it is a station that involves putting something together that kids can take back to their unit as opposed to just an activity they do.

\section{Nail Painting and Makeup/Face Painting}

I chose to have nail painting as one of the stations at Day of Self-Care based on my own Self-Care Plan (see Appendix 1). I enjoy nail painting as a part of my own self-care because it allows me to not only do something creative but it gives me time to myself. Usually, when I paint my nails I create flowers or try different techniques such as water marbling. All of this gives me a small creative outlet that I get to wear for the next week or so. I get to spend however long it takes me to paint my nails focusing on the task, rather than any of the stressors in my life. Nail painting also requires time for the polish to dry. This means for about an hour after my paint my nails, I can't do much except to relax. This is probably the best part because I am always doing something, so relaxing is an incredibly important piece to my self-care. The kids at Parry Center have liked this station in the past, so I wanted to make sure that I did keep it in this event as well. The kids should know that spending time doing something creative and fun is a completely legitimate tool to have in their toolkit.

Another station inspired by my Self-Care Plan is the makeup/face painting station. To me, makeup is part of each day that I get to completely focus on myself. Usually, it takes about 20 minutes for me to do my makeup and smile at myself in the mirror. My makeup helps me have the self-confidence that I do. If I think I look good, I feel good; If I feel good, I look good. I 
wanted to show this to the kids at Trillium because I noticed a lot of the girls were doing their makeup and I wanted them to understand that makeup could be a part of their own self-care. This station will also have face painting because makeup is usually something that girls do, and I wanted to make sure that all stations are accessible to every kid.

\section{Reflection and Next Steps}

To help with the reflection and the understanding of whether or not this project was a success I handed out anonymous and optional comment cards (see appendix.) The answers from these comment cards told me that the favorite station was the makeup and face painting station (see Figure 1). This was followed by the nail painting station. This was eye-opening to see because these are things that were inspired by my own self-care routine and I am glad that others saw the benefits from something simple like doing their nails. Another interesting thing from the comment cards was the kids absolutely loved the event. From these responses, on a scale of one to five (one being low and five being high), five was the average score. The kids were so passionate about this event that they even gave advice for the next event. Advice such as acquiring real makeup brushes, to try charcoal art, and to do something active. This idea of charcoal art is amazing because it forces the artist to make a mistake and fix it to end up with a beautiful piece. Doing something active was also an interesting idea for self-care because it allows each person to invest time into themselves and help them become healthier individuals. Potentially next time I would offer a station for yoga or a mindfulness walk around the campus.

The most meaningful part of this event was the chance to provide a safe space to talk to the kids about anything that they wanted to talk about. We talked about self-harm, confidence levels, and their families. It was awesome to see the genuine emotions come across the faces of 
all of the kids. Whether they were happy or curious or upset, it was a safe place for them to explore the different activities and all of the feelings they had inside of them.

Since the Day of Self-Care in February 2018, it has been moved from a quarterly event to a monthly event provided that enough volunteers are able to come in. Another impact I would like to see (if it is not already there) would be for the kids to create their own self-care plan and have access to the self-care techniques as long as it is feasible and appropriate for Trillium to provide that access. I think this is an important aspect for the kids because if they don't get to integrate self-care in lives during their stay at Trillium how will they be able to integrate it in their daily lives when they leave? Lastly, I want this paper to show the importance that self-care plays in each person's life so that they can think about it and incorporate it into their own daily lives. 


\section{References}

Bloom, Sandra L. (2017). The Sanctuary Model. Retrieved from: http://sanctuaryweb.com/.

Colori, S. (2018). Journaling as Therapy. Schizophrenia Bulletin, 44(2), 226-228.

Cooke, B., \& Ernst, E. (2000). Aromatherapy: A systematic review. The British Journal of General Practice: The Journal of the Royal College of General Practitioners, 50(455), 493-6.

Diego, MA, Jones, Na, Field, T, Hernandez-Reif, M, Schanberg, S, Kuhn, C, . . Galamaga, M. (1998). Aromatherapy positively affects mood, EEG patterns of alertness and math computations. International Journal of Neuroscience, 96(3-4), 217-224.

Stone, M. (1998). Journaling with Clients. Individual Psychology, 54(4), 535.

Ungerleider, S., \& Golding, J. (1991). Mental Practice among Olympic Athletes. Perceptual and Motor Skills, 72(3), 1007-1017.

Vandergon, Jaime (2017). “Co-Creating an Appreciative Trauma Informed Culture” [PowerPoint Presentation].

Weinberg, R. (2008). Does Imagery Work? Effects on Performance and Mental Skills. Journal of Imagery Research in Sport and Physical Activity, 3(1), Journal of Imagery Research in Sport and Physical Activity, 3(1). 
Appendix 1

\section{$\underline{\text { My Self-Care Plan }}$}

List the Personal Physical components of your self-care plan:

* Eating regularly

* Drink 3 bottles of water a day

* Doing my makeup

* Nail painting

List the Personal Psychological components of your self-care plan:

* Taking breaks from stressful/intense situations

* Personal reading

List the Personal Social components of your self-care plan:

* Spending time with family (regular dinners with parents and siblings)

* Spending time friends (birthday celebrations, girl's night, weekly brunch dates)

List the Personal Moral components of your self-care plan:

* Be honest

List the Professional components of your self-care plan:

* Take breaks during the workday

* Use a team for support

List the Organizational components of your self-care plan:

* Expect a high degree of cohesion

* Expect considerable flexibility of roles

List the Social/political components of your self-care plan:

* Community involvement. 
Figures

Figure 1.

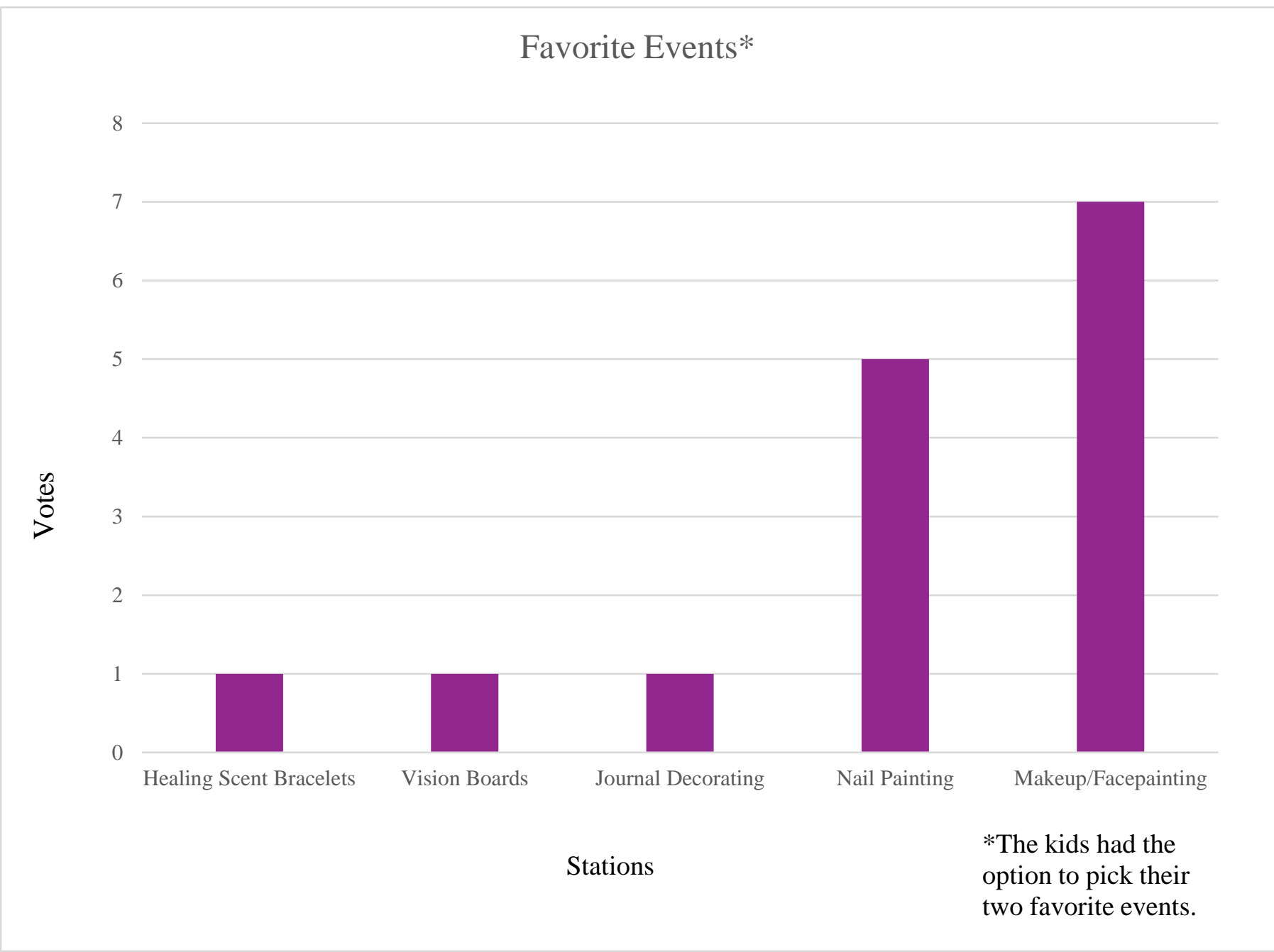

This figure shows the stations that were provided at Day of Self-Care and how many votes each station received a favorite event. As it is noted, each kid that filled out a comment card was able to pick up to two stations as their favorites. 